\title{
Hospital-based epidemiological study of reactions, Buluba Hospital, 1985-89
}

\author{
R. BWIRE \& H. J. S. KAWUMA \\ Buluba Leprosy Centre, P.O. Box 1059, Jinja (Uganda)
}

Accepted for publication 6 April 1993

\begin{abstract}
Summary A retrospective study of 256 reactional episodes, both reversal reaction and erythema nodosum leprosum (ENL), seen in Buluba Hospital over a 5 -year period (1985-89) was made. Over $90 \%$ of these episodes were due to reversal reaction, with ENL being encountered infrequently. About $80 \%$ of reversal reactions occurred during chemotherapy but all the episodes of ENL occurred during this period. Over $70 \%$ of both reversal and ENL episodes presented with clinically apparent nerve and skin involvement.

The need to assess the effect of multidrug therapy on the incidence of reactions and to develop more sensitive diagnostic tools to detect early neuritis is emphasized. It is also necessary to study those patients who develop recurrent reactional episodes.
\end{abstract}

\section{Introduction}

Reactions are a common phenomenon among leprosy patients and the early detection and proper management of reactional episedes is an important part of the success of any leprosy control programme. ' Unfortunately there is little information on the occurrence and distribution of these episodes in Uganda.

Buluba Hospital offers specialized services for the treatment of complications of leprosy including reactions. This study was carried out to establish some epidemiological characteristics of reactions and to provide a data base for future prospective studies on reactions.

\section{Materials and methods}

The case notes of all the patients admitted for reactions (reversal and erythema nodosum leprosum) over a 5-year period (1985-89) were retrieved from the hospital records office and analysed for: the type of leprosy, the type of reaction, age, sex, the timing of reactions, the type of chemotherapy, the pattern of reactions, and the frequency of reactional episodes. The hospital's annual reports for the same 5-year period were also consulted to obtain information about leprosy patients registered for chemotherapy in its catchment area. 
Table 1. Distribution of admissions by leprosy type

\begin{tabular}{lccr}
\hline & \multicolumn{2}{c}{ Number of patients for } & \\
\cline { 2 - 3 } & $\begin{array}{l}\text { Reversal } \\
\text { Leaction }\end{array}$ & ENL & Total \\
\hline BT & 130 & 0 & 130 \\
BB & 26 & 0 & 26 \\
BL & 32 & 9 & 41 \\
LL & 0 & 9 & 9 \\
Total & 188 & 18 & 206 \\
\hline
\end{tabular}

\section{Results}

GENERAL TRENDS

There were 2317 leprosy admissions during the 5-year study period and 206 of these were admitted for reaction. Some of the patients were admitted more than once, giving a total number of 256 admissions for the management of acute episodes - 231 were for reversal reaction ( $R R$ ) and 25 for erythema nodosum leprosum (ENL) reaction. Of 188 patients admitted for reversal reactions, $130(69 \cdot 1 \%)$ were classified as borderline tuberculoid. Only 18 patients presented with ENL (Table 1 ).

The combined total of registered patients for the 5-year period was 11,688-2743 $(23 \cdot 5 \%)$ belonged to the multibacillary type (BB, BL, LL), $4643(39 \cdot 7 \%)$ were the borderline tuberculoid type (BT) and $4302(36 \cdot 8 \%)$ were the TT type.

\section{REACTIONS AND AGE}

Age was known for $117(56 \cdot 8 \%)$ of the patients. The remaining $89(43 \cdot 2 \%)$ were simply recorded as 'adults'.

\section{REACTIONS AND SEX}

Of the 206 patients studied, 116 were males and 90 were females, a male to female ratio of $1 \cdot 3: 1$. Among those with reversal reaction, 103 were males and 85 were females, a male to female ratio of $1 \cdot 2: 1$. Of the 18 patients with ENL, 13 were males and 5 were females, a male to female ratio of $2 \cdot 6: 1$.

\section{TIMING OF REACTIONS}

This was taken as the period in which reactions occurred relative to chemotherapy-that is, before, during or after chemotherapy-206 (80.5\%) episodes occurred during chemotherapy, $38(14 \cdot 8 \%)$ before and $12(4 \cdot 7 \%)$ after chemotherapy. Of the $231 \mathrm{RR}$ episodes, $181(78.3 \%)$ occurred during chemotherapy, and all the 25 ENL episodes occurred during this period in 9 borderline lepromatous (BL) and 9 lepromatous leprosy (LL) patients. The RR episodes during chemotherapy occurred in 104 borderline tuberculoid (BT), 23 mid-borderline (BB) and $13 \mathrm{BL}$ patients. The RR episodes before 
chemotherapy occurred in 38 patients, 23 of whom were classified as BT, 3 as BB and 12 as BL. The RR episodes after chemotherapy occurred in 10 patients; $3 \mathrm{BT}$ and $7 \mathrm{BL}$. In this group all the patients, with the exception of 2 BT patients, had received multiple drug therapy. In 2 BT patients (including the patient with MDT), RR commenced within 6 months of stopping chemotherapy. In $6 \mathrm{BL}$ patients and the single BT patient, reactions developed between 6 and 12 months after stopping chemotherapy. In the remaining BL patient, the reaction occurred 2 years after stopping chemotherapy.

\section{CHEMOTHERAPY}

Of the 206 patients, 134 (65\%) were on multiple drug therapy (MDT), according to World Health Organization recommendations. ${ }^{2}$ For multibacillary patients who had positive skin smears after 2 years' treatment, MDT was continued up to smear negativity. In all, $117(62.2 \%)$ patients with RR and 17 of 18 patients with ENL were on MDT. The remaining 72 patients were on alternative regimens, including Dapsone monotherapy.

\section{PATTERN OF REACTIONS}

Of the 231 reversal episodes, $168(72 \cdot 7 \%)$ had involvement of both skin and nerves. Of the 25 ENL episodes, $18(72 \%)$ had both skin and nerves involved and $7(28 \%)$ had skin involvement alone.

\section{FREQUENCY OF EPISODES}

In total, $151(80 \cdot 3 \%)$ patients with RR suffered only 1 episode of reaction; $31(16 \cdot 5 \%) 2$ episodes and $6(3 \cdot 2 \%) 3$ episodes; 11 of the 18 patients with ENL had 1 episode and 7 had 2 episodes.

\section{Discussion}

It is estimated that by 1987 there were 10,613 registered leprosy patients in Uganda. ${ }^{3}$ In this same year 2094 patients were in the Buluba Leprosy Control area. Some of these patients risk developing reactions, and without prompt and proper treatment, disability and deformity can easily follow from nerve damage.

Little or no progress has been made in research on leprosy reactions and nerve damage, 2 important areas of prevention and treatment. ${ }^{4}$ Only a few studies based on population and community surveys on reactions and their epidemiology have been conducted, and, certainly, not in Uganda.

Reactions are the third commonest cause for admissions of leprosy patients to Buluba Hospital. ${ }^{5}$ Over the study period they accounted for $11 \%$ of leprosy admissions. The fact that the 256 admissions were taken out of a cumulative total of 11,688 patients suggests that reactions requiring hospital management arise in about $2 \cdot 2 \%$ of all registered patients. This figure is further confirmed because Buluba Leprosy Centre is the only facility in the area where patients with severe reactions are likely to be referred to or present themselves voluntarily. The patients in the catchment area are routinely visited by field workers. Boerrigter ${ }^{6}$ observed that $2 \cdot 2 \%$ of patients developed marked reactions during MDT. 
The commonest type seen was RR, which accounted for $90 \cdot 2 \%$ of reaction admissions. In this study ENL represented $9 \cdot 8 \%$ of the total reactions, a similar result to that reported by Becx-Bleumink ${ }^{7}$ in a study carried out in Ethiopia.

Because the ages of only $43 \cdot 2 \%$ of the patients were known, no realistic conclusions on age applicable to the whole group could be made.

There was a slight preponderance of males among those who developed reactions. Studies elsewhere have shown males to be more frequently affected up to a ratio of $6: 1 .^{8}$ There is a slight male preponderance, with respect to RR alone, while in the group who developed ENL, the male to female ratio was $2 \cdot 6: 1$. The latter observation may be related to the fact that there are generally fewer females with BL and LL leprosy. ${ }^{9}$

Most of the reactions ( $80 \cdot 5 \%)$ occurred during chemotherapy, with all ENL episodes occurring during this period. A total of $65 \%$ were on MDT. The MDT coverage in this area during this period rose from about $6 \%$ in 1986 to about $69 \%$ in $1989 .{ }^{10} \mathrm{~A}$ more specific study is needed to establish if MDT is related to the frequency of reactional episodes. The observation that $4 \cdot 6 \%$ of reactions presented after completion of chemotherapy could be used to determine whether post-treatment surveillance is costeffective or not, but it would have to be calculated against the size of the population at risk and preferably for each leprosy type, as was the case in the study of Becx-Bleumink. ${ }^{7}$

The Ugandan reaction pattern has already been described by Blenska, " but without quantitative data. In our study, $72.7 \%$ of reversal episodes presented with symptoms and signs involving skin and nerves while 13 out of $18 \mathrm{ENL}$ reactions involved both skin and nerves. That none of the patients had neuritis alone without skin manifestations could be due to lack of specific diagnostic tools in Buluba's Leprosy Control Programme.

It is noteworthy that $19 \cdot 7 \%$ of all RR patients and 7 out of 18 ENL patients experienced more than one episode. Recurrent reactional episodes are associated with a great risk of developing permanent nerve damage. This group of patients should be studied to determine why they are prone to such recurrent reactional episodes.

\section{Acknowledgement}

We are grateful to Dr H. D. Engers of WHO, Geneva, formerly Secretary to the IMMLEP Steering Committee for encouraging us to undertake this study.

\section{References}

1 WHO. A Guide to Leprosy Control. 2nd Edition. WHO: Geneva, 1988.

2 WHO Study Group. Chemotherapy of leprosy for control programmes. Technical Report Series No. 675. WHO: Geneva, 1982.

3 WHO. Report of the inter-regional conference on leprosy control in Africa. Brazzaville, 1989.

${ }^{4}$ Engers H, Ji Baohong. UNDP/WORLD BANK/WHO special programme for research and training in tropical diseases. TDR News, 1988.

5 Kawuma HJ. Buluba Leprosy Hospital, Uganda: A review of admissions, 1981-1984. Lepr Rev, 1987; 58: 257-62.

6 Boerrigter G, Ponnighaus JM, Fine PEM. Preliminary appraisal of a WHO-recommended multiple drug regimen in paucibacillary leprosy patients in Malaŵi. Int J Le pr, 1988; 54: 408-17.

7 Becx-Bleumink M and Berhe D. Occurrence of reactions, their diagnosis and management in leprosy patients treated with multidrug therapy; experience in the leprosy control programme of the All Africa Leprosy and Rehabilitation Training Centre (ALERT) in Ethiopia. Int J Lepr, 1992; 60: 161-72. 
${ }^{8}$ Sehga! VN, Sharma V. Reactions in leprosy - a prospective study of clinical, bacteriological, immunological and histopathological parameters in thirty-five Indians. J Dermatol, 1988; 15: 412-19.

9 Noorden SK. The epidemiology of leprosy. Hastings RC, (ed.). London: Churchill Livingstone, 1985; pp. 1530.

${ }^{10}$ Kawuma HJS. St. Francis Leprosy Centre, Buluba, Uganda. Annual Report, 1989.

II Blenska W. Pattern of leprosy reactions in Uganda. Int J Lepr, 1971; 39: 433-43.

Lepr Rev (1993) 64, 325-329

\section{Etude épidémiologique des réactions conduite en milieu hospitalier, Hôpital Buluba, 1985-1989}

\section{R. BWire ET H. J. S. KaWuma}

Résumé Nous avons fait une étude rétrospective de 256 épisodes réactionnels, tant réactions lépreuses qu'érythème noueux lépreux (ENL), observés à l'Hôpital Buluba sur une période de cinq ans (1985-1989). Plus de $90 \%$ de ces épisodes étaient dus à des réactions lépreuses tandis que l'érythème noueux était peu fréquemment observé. $80 \%$ environ des réactions lépreuses ont eu lieu pendant la chimiothérapie mais tous les épisodes d'ENL se sont présentés pendant cette période. Plus de $70 \%$ des épisodes de réactions lépreuses et d'ENL ont présenté des complications nerveuses et cutanées cliniquement visibles.

Nous soulignons le besoin d'évaluer l'effet d'un traitement médicamenteux combiné sur l'incidence des réactions et de développer des outils de diagnostic plus sensibles pour détecter la névrite précoce. Il y a également lieu d'étudier le cas des sujets qui développent des épisodes réactionnels récurrents.

\section{Estudio epidemiológico de reacciones dentro de un hospital, Hospital Buluba, 1985- 1989}

\section{R. BWIRE Y H. J. S. KaWUMA}

Resumen Se efectuó un estudio retrospectivo de 256 episodios de reacciones, tanto de inversión como de eritema nodosum leprosum (ENL), observados en el Hospital Buluba durante un período de cinco años (198589). Más de un $90 \%$ de est os episodios se debió a una reacción inversa, siendo muy poca la frecuencia de ENL. Aproximadamente un $80 \%$ de las reacciones inversas ocurrieron durante la quimioterapia, mientras que todos los episodios de ENL se produjeron durante este período. Más de un 70\% de los episodios de inversión y de ENL se presentaron con participación de nervio y piel clínicamente aparente. Se enfatiza la necesidad de evaluar el ef ecto de la terapia de drogas múltiples sobre la incidencia de reacciones, y también de dessarrollar instrumentos de diagnóstico con mayor sensibilidad para una temprana detección de la neuritis. También es necesario estudiar a los pacientes que desarrollan episodios reactivos recurrentes. 